\title{
RUMAH TANGGA MIGRAN DAN KESEHATAN ANAK YANG DITINGGALKAN ANALISA DATA SAKERTI 2007
}

\author{
Cecep Sukria Sumantri \\ Survey METER (Survey, Measurement, Training, and Research) Yogyakarta \\ Email: cecep_sumantri@yahoo.co.id
}

\begin{abstract}
This paper discuss about migrant household and the health outcome of the children's age 0-14 years old. Using data IFLS at 2007, this paper has a purpose knowing the condition of child health at the migrant household where father's migrant, mother's migrant, parental migrant, and non migrant household. Using on the data of IFLS at 2007, founded 13.402 respondents at age 0-14 years old. Those are involves 505 children $(3,8 \%)$ live at migrant father household; 285 children $(2,1 \%)$ live at migrant mother household; 105 children (0,8\%) live at father-mother migrant household and 12.507 children (93,3\%) live at non migrant household. The result of this analysis such as: (1) the health status of children left hebind lower than children who's living with their parent; (2) non migrant household is more educated, because the year of schoolingof household's head and the caregiver of the children 0-14 years old are higher than migrant household; (3) the absenteeism of mother on child health status (based on the result of the nurse observation, $\mathrm{BMI}$ and $\mathrm{Hb}$ level) at migrant mother household is lower than the child health at the others migrant household; (4) household in the urban area gives a positive impact on the health status based on the result of the nurse observation and BMI, but gives negative impact (decrease) on the child's $\mathrm{Hb}$ level; (5) the increase of per capita expenditure gives a significant impact toward the increase of health child status based on the observation of nurse and BMI, but gives the decrease impact on $\mathrm{Hb}$ level and BMI after has been interacted by migrant household status.
\end{abstract}

\section{Keywords: Migration, Child left behind, Child health, IFLS}

\begin{abstract}
ABSTRAK
Tulisan ini membahas tentang rumah tangga migran dengan kesehatan anak usia 0-14 tahun. Dengan menggunakan data IFLS tahun 2007, tulisan ini bermaksud untuk mengetahui keadaan kesehatan anak di rumah tangga ayah migran, di rumah tangga ibu migran, di rumah tangga ayah-ibu migran, dan rumah tangga non-migran. Berdasarkan data IFLS 2007 diperoleh sebanyak 13.402 anak berumur 0-14 tahun, di mana 505 anak (3,8\%) tinggal di rumah tangga ayah migran; sebanyak 285 anak $(2,1 \%)$ tinggal di rumah tangga ibu migran; sebanyak 105 anak (0,8\%) tinggal di rumah tangga ayah-ibu migran, dan sebanyak 12.507 anak $(93,3 \%)$ tinggal di rumah tangga non-migran. Temuan dari hasil analisa ini antara lain: (1) status kesehatan anak di rumah tangga migran lebih rendah dari anak yang tinggal di rumah tangga non-migran; (2) rumah tangga non-migran merupakan rumah tangga yang lebih terdidik, karena jumlah tahun sekolah kepala rumah tangga dan pengasuh anak usia 0-14 tahun di rumah tangga non-migran lebih tinggi; (3) ketidakadaan ibu sebagai pengasuh dan perawat anak menyebabkan status kesehatan anak (hasil pengamatan perawat, IMT, dan kadar $\mathrm{Hb}$ ) di rumah tangga ibu migran lebih rendah dibandingkan dengan kesehatan anak di rumah tangga migran lainnya; (4) status tempat tinggal di perkotaan memberikan pengaruh yang positif terhadap status kesehatan hasil pengamatan
\end{abstract}


perawat dan IMT, tetapi memberikan pengaruh negatif (penurunan) terhadap kadar $\mathrm{Hb}$ anak; (5) peningkatan per- capita expenditure memberikan pengaruh yang nyata terhadap peningkatan status kesehatan anak hasil pengamatan perawat dan IMT, tetapi memberikan pengaruh penurunan kadar $\mathrm{Hb}$ dan IMT setelah diinteraksikan dengan status rumah tangga migran.

Kata kunci: Migrasi, Anak yang ditinggalkan, Kesehatan anak, IFLS

\section{PENGANTAR}

Pengambilan keputusan untuk melakukan migrasi pada umumnya selalu ada keinginan seseorang untuk memperbaiki beberapa atau salah satu dari aspek kehidupan. Seseorang melakukan migrasi dapat disebabkan karena satu atau berbagai alasan, seperti untuk melanjutkan pendidikan, mendapatkan pekerjaan yang lebih baik, penghasilan yang lebih tinggi, mengikuti orang tua, mengikuti suami/isteri, famili atau orang lain, menikmati lingkungan yang lebih nyaman, atau menghindarkan diri dari beberapa hal yang tidak menyenangkan di daerah asal.

Migrasi yang dilakukan oleh individu pada dasarnya merupakan migrasi yang dilakukan secara sukarela, di mana individu yang melakukan migrasi tersebut telah memperhitungkan berbagai kemungkinan yang akan terjadi sebagai akibat dari perpindahan yang dilakukan. Hal ini termasuk memperhitungkan kerugian dan keuntungan yang akan diperoleh sebelum individu yang bersangkutan memutuskan untuk berpindah atau tetap menetap di tempat asal.

Harapan dari migrasi orang tua adalah adanyaremitanyangakanditerimaolehrumah tangga asal. Dengan remitan diharapkan dapat meningkatkan akses anak terhadap pendidikan, konsumsi makanan bergizi, dan akses ke fasilitas pelayanan kesehatan. Akan tetapi, sepertinya hal ini masih banyak diperdebatkan karena kenyataannya tidak selalu demikian. Remitan yang diterima oleh rumah tangga asal dapat berdampak positif dan dapat pula berdampak negatif.
Dampak positif dari remitan adalah apabila remitan tersebut antara lain semuanya atau sebagian besar digunakan untuk keperluan anak dan atau anggota rumah tangga lain yang ditinggalkan, seperti untuk biaya kesehatan, pendidikan anak, dan konsumsi makanan anak yang bergizi. Sebaliknya dampak negatif dari remitan yang diterima rumah tangga adalah jika remitan tersebut semuanya atau sebagian besar digunakan untuk membiayai pengeluaran rumah tangga yang sifatnya konsumtif, seperti perbaikan rumah, pembelian aset, dan lain-lain.

Di Indonesia pada umumnya dalam suatu rumah tangga tradisional bahwa tugas ayah antara lain mencari nafkah dan tugas ibu adalah mengasuh dan merawat anak. Akibatnya jika salah satu pergi meninggalkan rumah, maka dampak yang paling terasa bahwa akan terjadinya perubahan pola pengasuhan dan perawatan terhadap anak. Jika ayah pergi, pada umumnya ibu yang tinggal di rumah akan melakukan peran ganda sebagai kepala rumah tangga juga sebagai ibu rumah tangga. Sebaliknya jika ibu pergi, maka pada umumnya jarang ayah melakukan peran ganda sebagai kepala rumah tangga juga sebagai ibu rumah tangga karena biasanya pengasuhan anak di serahkan pada pembantu, saudara (kakak) atau mungkin juga serahkan pada nenek atau kakeknya. Jika ayah dan ibu pergi, maka sebagian besar rumah tangga menyerahkan pengasuhan anak mereka pada nenek-kakek dari anak yang ditinggalkan.

Berdasarkan uraian di atas, tulisan ini antara lain bertujuan untuk mengetahui hubungan antara rumah tangga migran dengan status kesehatan anak umur 0-14 tahun. Secara khusus tulisan ini ingin mengetahui status kesehatan anak yang bersifat subjektif dari hasil pengamatan, wawancara, dan status kesehatan obyektif dari pengukuran kesehatan secara objektif serta faktor-faktor yang mempengaruhinya. Penelaahan secara rinci tentang status kesehatan anak di rumah tangga migran yang ditinggalkan orang tuanya perlu dilakukan karena hal ini sekurang- 
kurangnya dapat mengetahui apakah mobilitas penduduk merupakan salah satu faktor yang menyebabkan adanya perubahan status kesehatan anak yang ditinggalkan. Tulisan ini penting untuk disajikan karena diharapkan dapat memberikan sumbangan pada pengembangan kajian kependudukan dan kesehatan masyarakat dan pemahaman tentang "biaya" migrasi terhadap anggota rumah tangga yang ditinggalkan.

\section{Definisi anak}

Anak di definisikan sebagai individu di bawah umur 18 tahun (dokumen CRC: section II, artikel 1 : 43). Akan tetapi, di dalam tulisan ini anak dikelompokkan ke dalam umur 0-14 tahun. Hal ini karena dalam dalam Survey Ketenagakerjaan Nasional, batas bawah usia seseorang memasuki pasar kerja dihitung mulai umur 15 tahun. Selain itu pula, dalam studi-studi atau survey yang berkaitan dengan fertilitas, batas bawah usianya adalah 15 tahun. Demikian halnya dalam Survey Aspek Kehidupan Rumah Tangga Indonesia (IFLS), di mana anak dikelompokkan pada usia 0-14 tahun, dan usia dewasa berada pada kelompok umur 15 tahun atau lebih.

\section{Migrasi dan Kesehatan Anak}

Migrasi sebagai salah satu bentuk dari mobilitas geografi atau mobilitas keruangan (geographic or spatial mobility) dari satu unit geografi ke unit geografi lainnya yang menyangkut suatu perubahan tempat tinggal secara permanen dari tempat asal atau tempat keberangkatan ke tempat tujuan atau tempat yang di datangi (Alatas, 1993). buku pedoman migrasi PBB memberikan batasan bahwa migran adalah seseorang yang berpindah tempat kediaman dari suatu unit daerah administratif atau politis tertentu ke unit daerah administratif atau daerah politis yang lain (United Nations, 1970:2). Alasan ekonomi merupakan dorongan yang utama seseorang untuk melakukan migrasi (Hugo, 1978:459), Mantra (1978: 220), Todaro (1969:28), dan Lee (1970:289). Bahkan sampai dengan saat ini, terutama di negara-negara sedang berkembang motif ekonomi masih mendominasi alasan migrasi

Migrasi individu baik satu atau beberapa orang anggota rumah tangga akan memberikan dampak positif dan negatif terhadap rumah tangga yang ditinggalkannya, baik ekonomi, sosial maupun masyarakat yang berada di lingkungannya tinggal sebelumnya. Demikian halnya dengan migrasi individu orang tua (baik migrasi yang dilakukan oleh ayah saja, migrasi oleh ibu saja atau migrasi keduanya secara bersamaan) dapat secara langsung mempengaruhi terhadap keluarga dan terutama adalah anak yang ditinggalkan.

Kepergian orang tua menjadi migran tidak saja berpengaruh terhadap kehidupan anak sehari-hari, tetapi juga berpengaruh terhadap hubungan dengan orang tua pengganti di rumah. Hal tersebut merupakan fenomena yang banyak terjadi dan menjadi masalah jika ibu pergi meninggalkan rumah untuk menjadi migran. Sementara ayah di rumah mencari teman baru dan meninggalkan anak-anaknya dengan pengasuh (Salah, 2008:13).

Studi dampak Immigrasi terhadap kesehatan anak dengan menggunakan data Survey Migrasi Pulau Pasifik Selandia Baru. Hasilnya menunjukkan bahwa migrasi memberikan dampak yang komplek terhadap kesehatan anak, yaitu meningkatkan tinggi badan bayi dan balita. Tetapi juga meningkatkan BMI dan obesitas pada usia pra-remaja (Stillman, dkk: 2007).

Pada umumnya peran ibu dalam rumah tangga berkaitan dengan pekerjaan domestik, seperti mengurus rumah, memasak, mencuci, mengantar anak ke fasilitas kesehatan, membantu mengerjakan perkerjaan rumah anak, dan mengawasi anak selama waktu senggang. Peran ayah mencari uang, tetapi banyak pula pekerjaan rumah tangga yang dikerjakan bersamasama dengan pasangannya di rumah. Studi yang dilakukan oleh yang mengkaji dampak migrasi terhadap anak di Moldova, ditemukan bahwa jika salah satu atau kedua orang tua pergi untuk menjadi migran, maka 
akan terjadi pembentukan kembali peran gender (ibu) dan distribusi tanggungjawab di rumah yang ditinggalkan (Salah, 2008). Perubahan tersebut tergantung dari siapa yang pergi menjadi migran, jika ayah yang menjadi mingran, maka $64 \%$ pasangan (ibu-istri) yang ditinggalkan melanjutkan perannya menjadi pengasuh secara langsung. Sedangkan jika ibu yang pergi menjadi migran, hanya $46 \%$ pasangan (ayah-suami) yang melakukan peran sebagai pengasuh dan mengerjakan perkerjaan yang sebelumnya dilakukan oleh istrinya. Ketika ibu pergi menjadi migran, maka semua pengasuhan/ perawatan dan pelayanan yang diberikan kepada anaknya adalah yang paling banyak berubah (salah, 2000:10).

Akibat dari migrasi orang tua, maka akan terjadi perubahan struktur di rumah tangga dan perawatan terhadap anak yang ditinggalkan. Secara normal, perubahan tersebut dipengaruhi oleh beberapa faktor, seperti jenis kelamin orang tua yang menjadi migran, hubungan keluarga dengan pengasuh anak yang ditinggalkan, keberadaan anak lain di rumah tersebut, dan sikap baik langsung maupun tidak langsung dari pengasuh. Perubahan yang lain adalah menurunnya sistem pengawasan dan perlindungan terhadap anak yang biasa diberikan oleh orang tuanya untuk meminimkan gangguan pada anak sebelum mereka pergi menjadi migran. Ketika kedua orangtuanya menjadi migran, anak-anak yang lebih dewasa sering terlewat dari perawatan kakek atau neneknya. Beberapa kasus, anak-anak mereka ditinggalkan, dan anak yang lebih dewasa berperan sebagai pengasuh. Beberapa responden anak yang diwawancara menyatakan bahwa kakek dan neneknya adalah bukan pengasuh yang terbaik, terutama jika anak yang beranjak dewasa. Anak-anak sering stress dan hilang/ kurang percaya diridan menjadi korban kekerasan (Salah, 2000:11).

Ketidakadaan orang tua dapat mempengaruhi kesehatan fisik dan mental anak. Sebanyak $87 \%$ keluarga yang di survey oleh UNICEF-UNDP tahun 2007 menyatakan bahwa anak-anak yang tinggal dengan orang tuanya lebih sehat dibandingkan dengan $69 \%$ anak di keluarga yang orang tuanya menjadi migran (Salah, 2008:18). Salah satu penyebabnya adalah status gizi setelah ditinggal oleh orang tuanya, di mana anak tidak makan secara teratur sehingga memberikan dampak negatif terhadap kesehatannya. Menurut studi CRIC tahun 2006, alasan lain tentang kesehatan anak yang orang tuanya menjadi migran adalah menjadi tertutup terhadap masalah kesehatan dan menunda kunjungan ke dokter dengan berbagai alasan.

Studi tentang dampak migrasi terhadap kesehatan anak yang ditinggalkan telah dilakukan oleh Escalante pada tahun 2008 di Cagayan de Oro City Mindanao Piliphina. Rumah tangga tanpa migran diperlakukan sebagai rumah tangga kontrol dan rumah tangga dengan migran sebagai rumah tangga treatment. Rumah tangga yang menjadi sampel pada studi ini sebanyak 60 rumah tangga, di mana 30 rumah tangga sebagai kontrol, dan 30 rumah tangga sebagai treatment. Pada studi tersebut Escalante menggunakan beberapa variabel penelitian yang antara lain adalah jumlah anak yang ditinggalkan, lama migran meninggalkan rumah, remitan (frekuensi dan jumlahnya), penggunaan remitan, umur anak ketika orang tua meninggalkan rumah, umur anak saat survey, vaksinasi anak, tanda dan gejala penyait yang diderita anak, pengobatan anak selama sakit, siapa yang mengobati anak pada saat sakit, kunjungan ke petugas kesehatan untuk memeriksa kesehatan, petugas kesehatan yang melayani pemeriksaan kesehatan, dan minum vitamin. Studi Escalante ini menunjukkan dampak positif dan negatif dari migrasi terhadap kesehatan anak. Hasil studi menunjukkan bahwa anak di rumah tangga dengan migran telah lengkap mendapat vaksinasi dan konsumsi vitamin. Akan tetapi, ditemukan bahwa di keluarga migran lebih tinggi tendensi tidak membawa anak ke dokter untuk memeriksa kesehatan rutin. 
Berdasarkan keterangan tersebut di atas, maka kerangka pemikiran dari tulisan ini adalah status kesehatan anak dipengaruhi oleh status rumah tangga migran dan juga dipengaruhi oleh beberapa faktor yang berhubungan, seperti karakteristik rumah tangga yang ditinggalkan, karakteristik kepala rumah tangga, karakteristik pengasuh, dan karakteristik anak yang bersangkutan.

\section{Rumah tangga sampel dan unit analisis}

Rumah tangga sample pada tulisan ini adalah rumah tangga yang memiliki anggota rumah tangga berumur 0-14 tahun. Unit analisisnya adalah individu usia 0-14 tahun. Berdasarkan data IFLS 2007 diperoleh data sebanyak 13.402 anak berusia 0-14 tahun.

\section{Batasan operasional dan pengukuran variabel}

Variabel independen yang ingin diketahui pengaruhnya terhadap kesehatan anak adalah status rumah tangga yang dibedakan menjadi 3, yaitu (1) Rumah tangga ayah migran ( $h h_{-} m g \_f a$ ), yaitu rumah tangga hanya ayah yang menjadi migran, dengan skala variabel $1=$ rumah tangga dimana ayah migrant, $0=$ lainnya. (2) Rumah tangga ibu migran (hh_mg_ma), yaitu rumah tangga hanya ibu yang menjadi migran, dengan skala variable $1=$ rumah tangga dimana ibu migran, 0=lainnya. (3) Rumah tangga ayahibu migran ( $h h_{-} m_{\text {g_f }}$ ( $)$ ), yaitu rumah tangga ayah dan ibu menjadi migran, dengan skala variabel $1=$ rumah tangga ayah dan ibu migran, $0=$ lainnya.

Berdasarkan status rumah tangga tersebut di atas, data IFLS 2007 ditemukan 505 anak (3,8\%) tinggal di rumah tangga hanya ayah saja migran; 285 anak $(2,1 \%)$ tinggal di rumah tangga hanya ibu saja migran; 105 anak (0,8\%) tinggal di rumah tangga di mana ayah dan ibu migran; dan 12.507 anak $(93,3 \%)$ anak tinggal di rumah tangga non-migran.

Variabel dependen pada tulisan ini adalah status kesehatan anak usia 0-14 tahun, yaitu pertama, Kesehatan anak 0-14 tahun, berdasarkan penilaian perawat kesehatan dengan cara membandingkan keadaan kesehatan anak (subjek) dengan anak lain yang berjenis kelamin dan umur yang sama. Skala penilaian oleh perawat 1 sampai 9, di mana skala 1 menggambarkan keadaan kesehatan anak yang sangat buruk dan skala 9 menggambarkan keadaan kesehatan anak yang sangat baik. Selanjutnya dilakukan pengkategorian $1=$ jika nilai $\geq 6$ dan $0=<6$. Kedua, Kadar hemoglobin dalam darah, yang diperoleh dari hasil pengukuran secara objektif dengan menggunakan Fotometer Hemocue. Ketiga, Pengukuran Indeks Masa Tubuh (Body Mass Index - BMI) dihitung berdasarkan data tinggi badan dan berat anak dengan rumus: $B M I=\frac{B B(K g)}{T B(m)^{2}}$.

Variabel yang digunakan sebagai kontrol meliputi: Pertama, Karakteristik rumah tangga, meliputi status kota-desa (urban), per capita expenditure (pce) yang dihitung berdasarkan pengeluaran rumah tangga pangan dan non- pangan perkapita, jumlah anggota rumah tangga (hhsize), hubungan dengan kepala rumah tangga sebagai anak (rel_child), hubungan dengan kepala rumah tangga sebagai cucu (rel_ grandchild). Kedua, Karateristik kepala rumah tangga, meliuti jenis kelamin (sex_hhhead), umur (age_hhead), pendidikan (educ_hhhead) dihitung berdasarkan tahun sukses sekolah. Ketiga, Karakteristik pengasuh, meliputi usia (age_ct), Pendidikan (educ_ct) yang dihitung berdasarkan tahun sukses sekolah, dan jenis kelamin (sex_ct). Keempat, Karakteristik individu anak, meliputi usia (age_child) dan jenis kelamin (sex_child).

\section{Metode Analisis}

Pembuatan data set dan analisis menggunakan perangkat lunak "Stata versi 11.1". Untuk memperoleh gambaran tentang keadaan karakteristik rumah tangga, karakteristik pengasuh, dan karakteristik anak di setiap status rumah tangga, maka dilakukan analisis deskriptif di setiap status rumah tangga. Untuk mengetahui kontribusi atau pengaruh rumah tangga migran terhadap 
status kesehatan anak, maka dilakukan analisa multivariat. Analisa dilakukan untuk mengetahui kontribusi variabel independen dan variabel kontrol terhadap status kesehatan anak. Untuk variabel dependen dengan skala 1:0, maka dilakukan analisis dengan regresi logistik, sedangkan untuk variabel dependen dengan skala kontinu (rasio) dilakukan dengan model regresi linier dengan model sebagai berikut:

Model 1 :

$$
\begin{aligned}
\mathrm{HS}= & \beta_{1} \lambda_{\text {hh_mg }}+\beta_{2} \lambda_{\text {hh_ch }}+\beta_{3} \lambda_{\text {child_ch }}+\beta_{4} \lambda_{\text {hhhead_ch }}+ \\
& \beta_{4} \lambda_{\text {ct_ch }}
\end{aligned}
$$

Dimana : HS = status kesehatan anak (Pengamatan perawat $/$ morbiditas), $\beta_{1 . . x}=$ nilai odd ratio, mulai dari variabel vektor pertama dan seterusnya, $\lambda_{\text {hhmg }}=$ vektor rumah tangga migran, $\lambda_{h h c h}=$ vektor karakteristik rumah tangga (urban, hhsize, pce,rel_child, rel_granchild), $\lambda_{\text {child_ch }}=$ vektor karakteristik anak (jenis kelamin dan umur), $\lambda_{\text {hhhead_ch }}=$ vektor karakteristik kepala rumah tangga (jenis kelamin, umur, dan pendidikan)

Model 2:

$$
\begin{aligned}
\mathrm{HS}= & \beta_{0}+\beta_{1} \lambda_{\text {hh_mg }}+\beta_{2} \lambda_{\text {hh_ch }}+\beta_{3} \lambda_{\text {child_ch }}+ \\
& \beta_{4} \lambda_{\text {hhhead_ch }}+\beta_{4} \lambda_{\text {ct_ch }}
\end{aligned}
$$

Di mana : HS = status kesehatan anak (hemoglobin/IMT), $\quad \beta_{0}=$ konstanta, $\beta_{1 . x}=$ koefisien prediksi variabel independen dan variabel kontrol, penjelasan $\lambda_{h h m g}$ sampai dengan $\lambda_{c t c h}=$ sama dengan penjelasan di atas.

\section{PEMBAHASAN \\ Analisa Deskriptif}

Secara keseluruhan, status kesehatan anak berdasarkan penilaian oleh perawat kesehatan di atas rata anak lain yang berjenis kelamin dan umur yang sama yaitu lebih besar dari 5 (Tabel 1). Berdasarkan Tabel 1 terlihat bahwa terdapat perbedaan status kesehatan anak yang signifikan antara yang tinggal di rumah tangga migran dan rumah tangga non-migran dengan nilai prob > F sebesar 0.003 . Rata-rata skala penilain tertinggi pada anak yang tinggal di rumah tangga non-migran, yaitu sebesar 5.86. Di antara anak yang tinggal di rumah tangga migran, skala penilaian kesehatan anak tertinggi pada anak di rumah tangga ayah migran, yaitu dengan nilai skala 5.86 dan rata-rata nilai skala yang terendah pada anak di rumah tangga ibu migran, yaitu sebesar 5,68 .

Kadar hemoglobin $(\mathrm{Hb})$ anak yang disajikan pada Tabel 1 menunjukkan bahwa terdapat perbedaan yang signifikan kadar $\mathrm{Hb}$ anak yang tinggal di rumah tangga migran dan rumah tangga non-migran dengan nilai prob > F 0.000. Meskipun terdapat perbedaan kadar hemoglobin, tetapi semua anak dengan kadar $\mathrm{Hb}$ normal ( $>12$ ). Kadar $\mathrm{Hb}$ tertinggi pada anak yang tinggal di rumah tangga ayah-ibu migran (12.68) dan yang terendah pada anak yang tinggal di rumah tangga non-migran (12.18).

Indeks masa tubuh anak yang disajikan pada Tabel 1 menunjukkan bahwa tidak ada perbedaan yang signifikan. Terlihat bahwa IMT teringgi pada anak yang tinggal di rumah tangga non-migran (19.35) dan yang terendah pada anak yang tinggal di rumah tangga ibu (16.20). Dua dari tiga indikator kesehatan anak yang disajikan pada Tabel 1 di atas menunjukkan bahwa status kesehatan anak yang tinggal di rumah tangga ibu migran ternyata lebih rendah dibandingkan dengan anak yang tinggal di rumah tangga lainnya, yaitu status kesehatan menurut penilaian oleh perawat, kadar $\mathrm{Hb}$, dan indeks masa tubuh. Karakteristik rumah tangga migrant dan rumah tangga non-migran yang disajikan pada Tabel 1 menunjukkan perbedaan yang signifikan untuk indicator tempat tinggal kota-desa (prob > F 0.000), jumlah anggota rumah tangga (prob > F 0.002) dan pengeluaran per kapita (prob > F 0.013). Secara keseluruhan rumah tangga nonmigran lebih banyak tinggal di perkotaan, dengan rata-rata jumlah anggota rumah tangga yang lebih banyak dari rumah tangga migran, dan rata-rata pengeluaran perkapita yang lebih besar dari rumah tangga migran. 
Tabel 1. Deskriptif Karakteristik

\begin{tabular}{|c|c|c|c|c|c|c|}
\hline & \multirow[b]{2}{*}{ Tipe data } & \multicolumn{4}{|c|}{ Independen Variabel } & \multirow[b]{2}{*}{ Statistic Uji } \\
\hline & & $\begin{array}{c}\text { Ayah } \\
\text { Migran }\end{array}$ & $\begin{array}{c}\text { Ibu } \\
\text { Migran }\end{array}$ & $\begin{array}{c}\text { ayah-ibu } \\
\text { migran }\end{array}$ & $\begin{array}{c}\text { Non- } \\
\text { Migran }\end{array}$ & \\
\hline Dependen Variabel : & & & & & & \\
\hline (health_nurse) & Mean & 5.83 & 5.68 & 5.81 & 5.86 & Prob > F 0.003 \\
\hline $\mathrm{Hb}$ level (hb) & Mean & 12,50 & 12,31 & 12,68 & 12,18 & Prob > F 0.000 \\
\hline IMT level (bmi) & Mean & 16,96 & 16,20 & 17,04 & 19,35 & Prob > F 0.636 \\
\hline \multirow{4}{*}{$\begin{array}{l}\text { Variabel Kontrol : } \\
\text { (urban_rural) } \\
\text { hhsize } \\
\text { (pce/1000) }\end{array}$} & & & & & & \\
\hline & $\%$ 1.Urban & 49.11 & 40.35 & 32.38 & 51.78 & $x^{2}$ pr. $=0.000$ \\
\hline & Mean & 4,80 & 4,67 & 4,87 & 5,00 & Prob > F 0.002 \\
\hline & Mean & 4,48 & 3,73 & 4,37 & 4,54 & Prob > F 0.013 \\
\hline (sex_child) & $\%$ 1.Male & 53.27 & 45.96 & 55.24 & 51.48 & $\times 2$ pr. $=0.194$ \\
\hline Age of child & Mean & 8,033 & 8,052 & 9,942 & 6,380 & Prob > F 0.000 \\
\hline rel_hhhead & $\%$ child & 62,57 & 41,40 & 0 & 83,17 & $\chi^{2}$ pr. $=0.000$ \\
\hline rel_hhhead & $\begin{array}{l}\% \\
\text { grandchild }\end{array}$ & 29,50 & 52,98 & 80,95 & 13,35 & $x^{2}$ pr. $=0.000$ \\
\hline (age_hhhead) & Mean & 44,11 & 51,21 & 56,90 & 41,16 & Prob > F 0.000 \\
\hline (sex_hhhead) & $\%$ 1.Male & 31.29 & 83.51 & 67.62 & 91.17 & $\chi^{2}$ pr. $=0.000$ \\
\hline (educ_hhhead) & Mean & 6,99 & 5,63 & 5,26 & 8,38 & Prob > F 0.000 \\
\hline (age_ct) & Mean & 37,830 & 46,884 & 50,457 & 34,539 & Prob > F 0.000 \\
\hline (sex_ct) & $\%$ 1.Male & 3.37 & 38.95 & 9.52 & 5.37 & $x^{2}$ pr. $=0.000$ \\
\hline (educ_ct) & Mean & 7,33 & 5,74 & 4,95 & 8,38 & Prob > F 0.000 \\
\hline $\mathrm{N}$ & & 505 & 285 & 105 & 12,507 & \\
\hline Persen & & 3,77 & 2,13 & 0,78 & 93,32 & \\
\hline
\end{tabular}

Karakteristik kepala rumah tangga menunjukkan adanya perbedaan usia, jenis kelamin, pendidikan yang signifikan antara kepala rumah tangga di rumah tangga migrant, dan rumah tangga non-migran dengan nilai prob > F sebesar 0.000. Rumah tangga migran antara lain ditandai dengan rata-rata usia kepala rumah tangga yang lebih tua, lebih banyak dengan kepala rumah tangga berjenis kelamin laki-laki dan dengan tingkat pendidikan (tahun sukses) kepala rumah tangga yang lebih rendah. Sedangkan karaktersitik kepala rumah tangga di rumah tangga non-migran sebaliknya.

Karakteristik pengasuh anak juga menunjukkan adanya perbedaan yang signifikan dengan nilai prob > F 0.000 antara karakteristik pengasuh yang ada di rumah tangga migran dan pengasuh di rumah tangga non-migran yaitu pada aspek usia, jenis kelamin, dan pendidikan. Secara keseluruhan di rumah tangga migran dengan ditandai dengan rata-rata usia pengasuh yang lebih tua dari pengasuh yang ada di rumah tangga non-migran; lebih banyak pengasuh berjenis kelamin laki-laki dan dengan tingkat pendidikan pengasuh yang lebih tinggi.

Berdasarkan uraian temuan di atas, maka secara umum status kesehatan anak di rumah tangga non-migran lebih baik dibandingkan dengan status kesehatan anak di rumah tangga migran dan lebih banyak tinggal di desa. Sebaliknya rumah tangga non-migran lebih banyak tinggal di perkotaan dan termasuk rumah tangga yang produktif dan berpendidikan lebih tinggi. 


\section{Analisa Multivariat}

Analisa multivariat dilakukan untuk mengetahui hubungan antara rumah tangga migran terhadap kesehatan anak. Hasil analisis multivariat ini juga menyajikan nilai odd rasio dan coefiien, hasil uji $t$ dan $z$ pada setiap variabel independen, juga $p$ value dengan level kepercayaan 1 persen, 5 persen, dan 10 persen.

Pada analisis multivariat ini ketiga rumah tangga migran disertakan secara bersamaan, sehingga dapat diketahui pengaruhnya secara bersama-sama pada satu variable dependen. Variabel kontrol seperti karakteristik rumah tangga, karakteristik anak, karakteristik kepala rumah tangga, dan karakteristik pengasuh juga disertakan bersama-sama pada saat dilakukana analisis multivariat. Analisa logistik regresi dilakukan pada variable dependen status kesehatan berdasarkan penilaian perawat, sedangkan regresi linier dilakukan pada variabel dependen kadar hemoglobin dan indeks masa tubuh. Status kesehatan yang akan diamati dengan analisa multivariat ini adalah status kesehatan berdasarkan hasil pengamatan perawat kesehatan, kadar hemoglobin $(\mathrm{Hb})$, dan Indeks Masa Tubuh (IMT).

\section{Status kesehatan anak}

Status kesehatan anak menurut penilaian perawat yang disajikan pada Tabel 2 menunjukkan bahwa pada rumah tangga ayah migran dan rumah tangga ibu migrant memberikan pengaruh yang signifikan terhadap status kesehatan anak pada taraf 5 persen dengan nilai odd ratio sebesar 0,787 dan 0,718 . Sedangkan di rumah tangga di mana ayah-ibu migran tidak memberikan pengaruh yang signifikan terhadap status kesehatan. Akan tetapi, dari ketiga status rumah tangga tersebut, ternyata rumah tangga hanya ibu migran dengan nilai odd ratio yang terkecil (0.718). Status kesehatan anak bersifat subjektif karena status kesehatan ini berdasarkan pengamatan perawat kesehatan dengan cara membandingkan subjek dengan anak lain yang berjenis kelamin dan usia yang sama.
Variabel kontrol lain yang dianalisa dan memberikan pengaruh yang signifikan terhadap status kesehatan anak dengan nilai odd rasio $>1$ antara lain status tempat tinggal kota-desa, jumlah anggota rumah tangga, pengeluaran perkapita, umur anak, usia kepala rumah tangga, dan pendidikan pengasuh anak. Artinya variabel kontrol tersebut memberikan kontibusi pada kesehatan anak sebesar nilai odds rasionya. Demikian sebaliknya jika nilai odds rasio < 1, maka akan memberikan kontribusoi berkurang terhadap status kesehatan anak sebesar nilai odds rasionya.

Pada rumah tangga ayah migran 96,63 persen yang mengasuh anak adalah perempuan, di rumah tangga ibu migran 61,05 persen anak diasuh oleh perempuan, dan di rumah tangga ayah-ibu migran 94,63 persen anak akan diurus oleh perempuan (lihat Tabel 1). Secara umum, perhatian, perawatan, kepedulian, dan kasih sayang ibu terhadap anak akan lebih besar dibandingkan dengan pengasuh yang lainnya, meskipun dengan ayah kandungnya atau saudara-saudara kandung dan saudara bukan kandung lainnya. Hal inilah yang diduga menyebabkan status kesehatan anak di rumah tangga ayah migran lebih baik dibandingkan dengan rumah tangga migran lainnya. Akan tetapi, harus juga diketahui faktor atau variabel lain yang memberikan pengaruh yang signifikan pada status kesehatan anak.

Tabel 2 . Analisis Status Kesehatan Anak oleh Pengamatan Perawat

\begin{tabular}{|l|l|l|l|}
\hline VARIABLES & $\begin{array}{c}\text { odds } \\
\text { ratio }\end{array}$ & Std Err & $\mathbf{p}>\mathbf{z}$ \\
\hline hh_mg_fa & $0.787^{* *}$ & $(0.0847)$ & 0.026 \\
hh_mg_mo & $0.718^{* *}$ & $(0.0942)$ & 0.012 \\
hh_mg_fm & 0.746 & $(0.162)$ & 0.179 \\
urban_rural & $1.073^{*}$ & $(0.0439)$ & 0.083 \\
hhsize & $1.087^{* * *}$ & $(0.0135)$ & 0.000 \\
pce_n & $1.053^{* * *}$ & $(0.00700)$ & 0.000 \\
rel_child & 1.040 & $(0.105)$ & 0.695 \\
rel_grdchild & 1.126 & $(0.140)$ & 0.340 \\
sex_child & 0.980 & $(0.0374)$ & 0.604
\end{tabular}




\begin{tabular}{|l|l|l|l|} 
age_child & $1.013^{* *}$ & $(0.00519)$ & 0.012 \\
sex_hhhead & $0.729^{* * *}$ & $(0.0511)$ & 0.000 \\
age_hhhead & $1.004^{*}$ & $(0.00259)$ & 0.097 \\
educ_hhhead & 1.008 & $(0.00611)$ & 0.203 \\
age_ct & 1.000 & $(0.00106)$ & 0.723 \\
sex_ct & $0.790^{* * *}$ & $(0.0626)$ & 0.003 \\
educ_ct & $1.029^{* * *}$ & $(0.00660)$ & 0.000 \\
& & & \\
\hline Observations & 13,286 & & \\
\hline
\end{tabular}

seEform in parentheses

*** $\mathrm{p}<0.01,{ }^{* *} \mathrm{p}<0.05,{ }^{*} \mathrm{p}<0.1$

Pengeluaran rumah tangga perkapita memberikan pengaruh yang nyata pada kesehatan anak. Pengeluaran rumah tangga ini dapat menggambarkan tingkat konsumsi rumah tangga yang juga dapat digunakan sebagai proksi terhadap pendapatan rumah tangga. Pada rumah tangga migran, pendapatan rumah tangga sebagian besar atau semuanya diterima dari migran. Hal ini seperti yang diungkapkan dari laporan Bank Dunia Moldova tahun 2005, bahwa 80 persen migran Moldova mengirim dana dan lebih dari 70 persennya mengirim lebih dari setengah pendapatannya pada rumah tangga asal. Sebagian besar penggunaan uang untuk pengeluaran dasar seperti konsumsi rumah tangga, untuk konsumsi bahan tahan lama, perbaikan rumah, pembayaran hutang, dan yang digunakan untuk investasi usaha kurang dari 7 persen (Salah, 2008:5). Lebih lanjut dikemukakan bahwa pengeluaran terbesar dari reremitan yang diterima adalah untuk konsumsi makanan, pakaian, kesehatan, dan pendidikan.

Pada dasarnya income dan pendidikan saling timbal-balik berdampak terhadap kesehatan. Income atau pendapatan dapat berinteraksi dengan pendidikan yang dapat meningkatkan pengetahuan dan wawasan tentang kesehatan yang pada akhirnya dapat mempengaruhi perilaku hidup sehat. Selanjutnya income dapat meningkatkan daya beli masyarakat. Akan tetapi, secara empiris sering ditemukan efek pendidikan terhadap kesehatan seperti juga dampak dari income. Secara statistic ada hubungan antara income dan status kesehatan yang dikontrol oleh variable usia, jenis kelamin, wilayah metropolitan/perkotaan), dan pendidikan (Lopez, 2004 dalam Feinstein, 2006:293). Temuan Mellor and Milyo (2002) dalam Feinstein (2006:293) tentang adanya hubungan antara income dengan berbagai outcome status kesehatan.

Hasil analisis juga menunjukkan bahwa pendidikan memberikan nilai odd rasio $>1$ dan positif, artinya pendidikan memberikan pengaruh yang baik pada kesehatan. Akan tetapi, seperti halnya income, pendidikan juga dapat memberikan pengaruhnya pada kesehatan dengan adanya faktor antara. Individu dengan kualifikasi tingkat pendidikan yang lebih tinggi lebih banyak mengunjungi ke fasilitas kesehatan dibandingkan dengan kualifikasi pendidikan yang lebih rendah (Feinstein, 2006:266). Di Amerika serikat, Deb and Trivedi (2002) dalam Feinstein (2006:266) menemukan bahwa tahun sukses sekolah berkorelasi positif terhadap jumlah kunjungan rawat jalann lainnya.

Uraian di atas memberikan gambaran bahwa status kesehatan anak di rumah tangga ibu migran lebih rendah dibandingkan dengan rumah tangga lainnya setelah di control oleh jenis kelamin pengasuh dan kepala rumah tangga, jumlah anggota rumah tangga, income, dan pendidikan.

\section{Kadar Hemoglobin}

Hasil analisis yang disajikan pada Tabel 3 menunjukkan bahwa pada rumah tangga di mana hanya ayah migran yang memberikan dampak signifikan pada taraf kepercayaan 5\% terhadap kadar hemoglobin anak dengan koefisien 0,16. Sedangkan di rumah tangga di mana ibu migrant dan rumah tangga ayahibu migrant tidak memberikan pengaruh yang signifikan. Informasi yang disajikan pada Tabel 3 tersebut menunjukkan bahwa nilai koefisien kadar hemoglobin pada anak yang terbesar pada anak yang tinggal di rumah tangga di mana hanya ayah yang migran, sedangkan yang terendah pada anak yang tinggal di rumah tangga di mana hanya ibu yang migran. 
Tingginya koefisien kadar hemoglobin pada rumah tangga ayah migran ini diduga karena masih adanya ibu yang mengurus anak di rumah, sehingga anak masih memperoleh pengasuhan, perhatian, dan pengawasan di rumah. Temuan ini sesuai dengan temuan survey yang dilakukan oleh UNICEF, di mana peran pengasuhan anak di rumah tangga migran tergantung dari jenis kelamin orang tua yang menjadi migran. Ditemukan sebanyak 14 persen keluarga dengan ibu sebagai migran, di mana anakanaknya menyatakan bahwa mereka tidak pernah ada yang mengurus. Hasil survey juga menemukan bahwa sebanyak 23 persen keluarga migran tidak pernah membawa anaknya ke dokter dan sebanyak 10 persen keluarga tidak pernah mengurus tentang pendidikan anaknya (Salah, 2008).

Variabel kontrol lain yang dianalisis secara bersamaan dengan variabel rumah tangga migran yang memberikan pengaruh yang positif signifikan terhadap kadar hemoglobin anak adalah pengeluaran perkapita, usia dan jenis kelamin anak, usia dan pendidikan kepala rumah tangga, dan pendidikan pengasuh anak. Sedangkan variabel yang memberikan pengaruh negatif yang signifikan adalah status tempat tinggal kota-desa dan jumlah anggota rumah tangga.

Pendidikan merupakan salah satu faktor penting yang dapat memberikan pengaruh pada kesehatan anak karena pendidikan dapat memberikan dampak langsung pada setiap perubahan perilaku individu di masa depan. Sebagai contoh, dampak terhadap income, seperti yang dikemukakan oleh Fenstein bahwa income keluarga dipengaruhi oleh tingkat pendidikan keluarga yang pada akhirnya akan mempengaruhi tingkat income keluarga, kemudian income tersebut dapat memengaruhi kesehatan anak (Fenstei, 2006:201). Hal ini income sebagai mediator pengaruh pendidikan terhadap kesehatan anak. Dengan demikian dapat dijelaskan bahwa dampak pendidikan terhadap kesehatan karena pendidikan dapat meningkatkan income sehingga dapat meningkatkan kemampuan daya beli keluarga terhadap sumber daya yang produktif untuk dapat meningkatkan kesehatan.

Table 3 : Analisis Kadar Hb dan Indeks Masa Tubuh

\begin{tabular}{|c|c|c|c|c|c|c|c|}
\hline \multirow{2}{*}{ VARIABLES } & Kadar $\mathrm{Hb}$ & IMT & & & & & \\
\hline & Coef. & Std. Err & $P>t$ & Coef. & Std. Err & $P>t$ & \\
\hline \multirow{6}{*}{$\begin{array}{l}\text { hh_mg_fa } \\
\text { hh_mg_mo } \\
\text { hh_mg_fm } \\
\text { urban_rural } \\
\text { hhsize } \\
\text { pce_n }\end{array}$} & $0.160^{* *}$ & $(0.0632)$ & \multicolumn{2}{|c|}{0.011} & $-0.449^{* *}$ & $(0.187)$ & 0.017 \\
\hline & 0.00140 & $(0.0723)$ & \multicolumn{2}{|l|}{0.985} & -0.336 & $(0.226)$ & 0.138 \\
\hline & 0.0856 & $(0.120)$ & \multicolumn{2}{|l|}{0.475} & 0.308 & $(0.504)$ & 0.542 \\
\hline & $-0.0706^{* * *}$ & $(0.0238)$ & \multicolumn{2}{|l|}{0.003} & $0.326^{* * *}$ & $(0.0819)$ & 0.000 \\
\hline & $-0.0149^{* *}$ & $(0.00675)$ & \multicolumn{2}{|l|}{0.027} & -0.0296 & $(0.0224)$ & 0.187 \\
\hline & $0.00950^{* * *}$ & $(0.00310)$ & \multicolumn{2}{|l|}{0.002} & $0.0276^{* * *}$ & $(0.0104)$ & 0.008 \\
\hline rel_child & -0.00376 & $(0.0570)$ & \multicolumn{2}{|l|}{0.947} & $0.288^{*}$ & $(0.153)$ & 0.059 \\
\hline rel_grdchild & -0.0810 & $(0.0726)$ & \multicolumn{2}{|l|}{0.265} & 0.232 & $(0.214)$ & 0.278 \\
\hline sex_child & $0.0701^{* * *}$ & $(0.0218)$ & \multicolumn{2}{|l|}{0.001} & $-0.201^{* * *}$ & $(0.0763)$ & 0.009 \\
\hline age_child & $0.165^{* * *}$ & $(0.00322)$ & \multicolumn{2}{|l|}{0.000} & $0.0488^{* * *}$ & $(0.00873)$ & 0.000 \\
\hline sex_hhhead & 0.0223 & $(0.0393)$ & \multicolumn{2}{|l|}{0.570} & -0.123 & $(0.123)$ & 0.317 \\
\hline age_hhhead & $0.00333^{* *}$ & $(0.00148)$ & \multicolumn{2}{|l|}{0.025} & $0.00903^{*}$ & $(0.00494)$ & 0.067 \\
\hline educ_hhhead & $0.0105^{* * *}$ & $(0.00345)$ & \multicolumn{2}{|l|}{0.002} & $0.0271^{\text {** }}$ & $(0.0121)$ & 0.025 \\
\hline age_ct & -0.000251 & $(0.000420)$ & \multicolumn{2}{|l|}{0.550} & $0.00380^{* * *}$ & $(0.00147)$ & 0.010 \\
\hline sex_ct & 0.0664 & $(0.0456)$ & \multicolumn{2}{|l|}{0.145} & $0.364^{*}$ & $(0.192)$ & 0.057 \\
\hline educ_ct & $0.00969 * * *$ & $(0.00369)$ & \multicolumn{2}{|l|}{0.009} & $0.0206^{*}$ & $(0.0123)$ & 0.093 \\
\hline Constant & $17.68^{* * *}$ & $(0.211)$ & & $17.10^{* * *}$ & $(0.282)$ & 0.000 \\
\hline Observations & 5,196 & & \multicolumn{2}{|l|}{0.000} & 5,196 & & \\
\hline
\end{tabular}




\begin{tabular}{|l|c|c|c|c|c|c|c|}
\hline \multirow{2}{*}{ VARIABLES } & Kadar Hb & IMT & & & & & \\
\cline { 2 - 8 } & Coef. & Std. Err & P>t & Coef. & Std. Err & P $>\mathbf{t}$ & \\
\hline R-squared & 0.027 & & & 0.033 & & \\
\hline $\begin{array}{l}\text { Robust standard errors in parentheses } \\
* * *\end{array}<0.01,{ }^{* *} \mathrm{p}<0.05,{ }^{*} \mathrm{p}<0.1$ & & & \\
\hline
\end{tabular}

Di Indonesia, pada umumnya jika ayahibu migran, maka sebagian besar anak yang ditinggalkan diasuh oleh saudara dari ibu atau saudara dari ayahnya. Akan tetapi, tidak jarang pula anak mereka yang ditinggalkan diasuh oleh nenek-kakeknya. Hal seperti yang telah dikemukakan pada Tabel 1 bahwa rata-rata 42 persen hubungan anak dengan kepala rumah tangga sebagai cucu. Nenekkakek pada umumnya akan memberikan perhatian dan perawatan yang sangat besar terhadap cucu-cucunya terutama ketika ayahibunya menjadi migran. Hal pengasuhan dan perawatan anak, sebenarnya tidak diragukan lagi bahwa seorang ibu akan memberikan perhatian yang lebih besar terhadap anak dibandingkan dengan ayah atau sudarasaudaranya. Misalnya saja dalam hal pemberian makanan dan ibu akan selalu memberikan sesuatu yang terbaik untuk anaknya sehingga ketidakadaan ibu akan sangat berpengaruh sekali terhadap anak.

Ketika ayah dan ibu migran, maka anak diasuh oleh orang lain seperti pembantu, nenek-kakek, paman-bibi, saudara atau famili lainnya. Dengan demikian rumah tangga ini akan menerima kiriman remitan dari ayahibu yang menjadi migran tersebut untuk anak yang ditinggalkan, dan tidak menutup kemungkinan remitan yang dikirim oleh ayah-ibu ini lebih besar jika dibandingkan hanya ayah saja atau ibu saja yang migran. Dengan adanya kiriman remitan, maka pendapatan rumah tangga migran tersebut bertambah sehingga dapat memenui kebutuhan konsumsi rumah tangga. Temuan Salah bahwa remitan sebagian besar digunakan oleh keluarga untuk pembelian makanan, pakaian dan kebutuhan dasar lainnya. Dengan demikian, diduga bahwa rendahnya kadar $\mathrm{Hb}$ anak di rumah tangga ayah migran di perkotaan maupun rumah tangga ayah-ibu migran disebabkan karena faktor konsumsi makanan dan juga pola hidup bersih dan sehat. faktor makanan diduga disebabkan oleh kurang dan tidak bergizinya makanan yang dikonsumsi, terutama sekali makanan yang tidak atau kurang mengandung zat besi. Dimana pada akhir-akhir ini produsen makanan telah sedemikian rupa memproduksi makanan instant siap saji yang memang memberikan kecepatan dan kemudahan bagi konsumen, akan tetapi jika dilihat dari segi gizi memang masih ada yang kurang memenuhi standar kecukupan gizi. Faktor kebersihan ini antara lain meliputi kebersihan pakaian, lingkungan rumah, lingkungan tempat bermain, dan juga makanan (Salah, 2008:5).

Uraian di atas memberikan gambaran bahwa keberadaan orang tua sangat berpengaruh terhadap kadar $\mathrm{Hb}$ anak. Keberadaan ibu di rumah tangga sebagai faktor antara yang dapat memberikan pengaruh nyata terhadap peningkatan kadar $\mathrm{Hb}$ anak, sebaliknya ketidakadaan ibu menyebabkan penurunan kadar $\mathrm{Hb}$ anak. Alokasi pemanfaat remitan belum sepenuhnya digunakan untuk memenuhi kebutuhan kesehatan anggota rumah tangga yang ditinggalkan, dan diduga bahwa pemanfaatan utama remitan sebagian besar masih untuk memenuhi keperluan rumah tangga.

\section{Indeks Masa Tubuh}

Hasil analisa yang disajikan pada Tabel 3 ditunjukan bahwa rumah tangga ayah migran memberikan pengaruh yang signifikan dengan tingkat kepercayaan 5 persen terhadap IMT anak dengan nilai koefisian - 0.449. Demikian halnya dengan rumah tangga ibu migran, di mana meskipun tidak memberikan pengaruh yang signifikan, tetapi memberikan koefisien yang negatif terhadap IMT anak. CHAMPSEA (2012:52) 
dari hasil analisis multivariate menunjukkan pengaruh yang hampir sama yaitu tidak ada perbedaan yang nyata antara migrasi orang tua dengan kelebihan berat badan anak. Pada bagian yang lain juga dikemukakan bahwa kondisi kurusnya anak yang ditinggal tidak burhubungan dengan migran orang tua.

Beberapa variabel kontrol lain yang juga bersamaan di analisis dan memberikan pengaruh yang signifikan terhadap IMT anak adalah status tempat tinggal kota-desa; pengeluaran perkapita; hubungan dengan kepala rumah tangga sebagai anak; jenis kelamin anak; dan umur anak; umur kepala rumah tangga; pendidikan kepala rumah tangga; umur pengasuh; jenis kelamin pengasuh; dan pendidikan pengasuh.

Estimasi pengaruh pendidikan terhadap tinggi anak di Barazil tahun 1986, di mana secara umum menunjukkan bahwa pendidikan ibu perlawanan dengan pendidikan ayah dalam menyediakan makanan bergizi untuk anak. Temuannya adalah adanya pengaruh yang besar dari pendidikan, misalnya tinggi anak yang dikontrol oleh usia dan jenis kelamin meningkat sekitar 0.5 persen setiap penambahan satu tahun sukses sekolah pendidikan ibu. Ditemukan bukti pula bahwa di daerah perkotaan, dampak pendidikan ibu sangat besar, di mana hampir setengahnya meningkatkan tinggi 0.28 point (Thomas, Strauss and Henriques, 1991 dalam Feinstein, 2006:247).

Astuti juga menemukan bukti bahwa biasanya anak-anak yang ditinggal ibunya diasuh oleh nenek atau hanya tinggal dengan bapaknya. Secara fisik, hampir semua anak yang di tinggal ibunya mengalami lambat pertumbuhan dan rawan penyakit. Asupan gizi yang seharusnya di perolehdari ASI tidak dapat dipenuhi dan pola makan anak juga sangat bervariasi tergantung yang mengasuh (nenek), yang biasanya memberi makan menurut waktu senggang si nenek. Keadaan ini menyebabkan kondisi kesehatan anak yang rendah dan juga sangat rendah bahkan tidak terpikirkan bagi pengasuh (nenek) untuk membawa ke posyandu untuk mengikuti program-program pemeriksaan kesehatan atau imunisasi (Astuti, 2009).

Tingkat pendidikan dapat mencerminkan kemampuan untuk memahami berbagai aspek pengetahuan sesorang, termasuk pengetahuan tentang gizi. Pengetahuan tentang gizi telah diberikan baik melalui pendidikan formal maupun informal. Pendidikan non-formal yang dimaksud antara lain pendidikan yang berikan pada kegiatan kelompok sosial seperti PKK, Posyandu atau Organisasi Dharma Wanita. Semakin tinggi tingkat pendidikan, maka semakin besar akses pada media informasi, sehingga akan lebih mudah untuk memperoleh informasi tentang makanan dan kandungan gizi.

Analisa tentang hubungan antara tingkat pendidikan (laki-laki dan perempuan) dan pola konsumsi makanan di 3543 rumah tangga di China oleh Bhandari (2000), menunjukkan bahwa tingkat pendidikan laki-laki dan perempuan kepala rumah tangga memberikan pengaruh yang berbeda terhadap pola konsumsi makanan. Pendidikan perempuan memberikan pengaruh terhadap pola konsumsi secara independen tanpa ada pengaruh kontribusi pendapatan. Sebaliknya pendidikan laki-laki memberikan pengaruh pada pola konsumsi setelah diinteraksikan dengan pendapatan.

Beberapa hasil penelitian dinegara berkembang menunjukkan bahwa adanya hubungan yang signifikan antara tingkat pendidikan ibu dengan asupan gizi di tingkat rumah tangga. Hasil analisa multivariat di beberapa negara berkembang, termasuk Indonesia tingkat pendidikan ibu dipandang sebagai determinan penting dari asupan gizi atau pengelolaan gizi di tingkat rumah tangga. Dengan tingkat pendidikan yang lebih tinggi, para ibu dari rumah tangga berpendapatan rendah pun dapat lebih mampu untuk mengelola sumber daya yang dimilikinya di rumah tangganya secara lebih efisien dibandingkan para ibu yang berpendidikan rendah. Dengan kata lain, dengan pendidikan lebih baik ibu dapat memilih dan mengkombinasikan beragam 
jenis pangan dengan harga yang tidak mahal (Behran dan Walfe, 1987; Behram dkk,1988 dalam Hardiyansyah, 2007:55-74).

Pendidikan merupakan salah satu elemen yang digunakan untuk mengetahui indeks mutu sumber daya manusia sehingga dengan meningkatnya tingkat pendidikan, maka akan memberikan dampak terhadap meningkatnya pengetahuan dan wawasan kepala rumah tangga. Dalam hal ini kepala rumah tangga dapat memberikan dan mengarahkan pada anggota rumah tangga untuk mengonsumsi makanan yang bergizi yang baik untuk pertumbuhan dan kesehatan.

Uraian di atas memberikan gambaran bahwa IMT anak di pengaruhi oleh status rumah tangga migran, di mana ketidakadaan ayah-ibu memberikan dampak yang terbesar terhadap penurunan IMT anak. Peningkatan pengeluaran rumah tangga tidak memberikan pengaruh yang positif terhadap IMT anak di rumah tangga migran karena hal ini dipengaruhi pula oleh pendidikan kepala rumah tangga. Pendidikan kepala rumah tangga memberikan pengaruh positif terhadap IMT anak. Hal ini karena tingginya tingkat pendidikan kepala rumah tangga berkaitan dengan kemampuan kepala rumah tangga untuk mengelola makanan yang akan dikonsumsi oleh anggota rumah tangga. Semakin tinggi tingkat pendidikan, maka semakin tinggi tingkat kemampuan kepala rumah tangga untuk mengelola dalam memperoleh jenis makanan yang lebih efisien dan bergizi dengan sumber daya yang ada.

\section{SIMPULAN}

Rumah tangga ayah migran dan rumah tangga ibu migran memberikan pengaruh yang signifikan terhadap status kesehatan anak berdasarkan penilaian dari pengamatan perawat kesehatan, sedangkan rumah tangga ayah-ibu migran tidak memberikan pengaruh yang signifikan. Rumah tangga ayah migran memberikan pengaruh yang signifikan terhadap hasil pengukuran kadar $\mathrm{Hb}$ dan IMT, sebaliknya rumah tangga ibu migran dan rumah tangga ayah-ibu migran tidak memberikan pengaruh yang nyata.

Status kesehatan anak usia 0-14 tahun berdasarkan penilaian perawat kesehatan pada rumah tangga ibu migran lebih rendah ditunjukkan dengan odds ratio 0.718 dibandingkan dengan keadaan kesehatan anak di rumah tangga ayah migran maupun rumah tangga ayah-ibu migran. Demikian halnya dengan hasil analisa pengukuran kadar $\mathrm{Hb}$, di mana koefisien rumah tangga ibu migran lebih rendah dibandingkan dengan level kadar $\mathrm{Hb}$ anak di rumah tangga ayah migran, yaitu 0.0014. Ketidakadaan ibu di rumah memberikan dampak terhadap penurunan kadar $\mathrm{Hb}$ dan penilaian status kesehatan anak berdasarkan penilaian perawat kesehatan.

Beberapa variabel kontrol yang selalu turut memberikan pengaruh positif yang signifikan terhadap status kesehatan anak berdasarkan penilaian oleh perawat, kadar $\mathrm{Hb}$, dan IMT adalah pengeluaran perkapita, usia anak, dan pendidikan pengasuh antara lain status tempat tinggal kota-desa, pengeluaran perkapita, umur anak, dan pendidikan pengasuh anak. Akan tetapi, untuk mengetahui lebih pasti lagi, maka perlu dilakukan analisa dengan menginteraksikan variabel tersebut dengan variabel status rumah tangga migran. Variabel status tempat tinggal kota-desa memberikan pengaruh positif yang signifikan pada status kesehatan menurut penilaian perawat dan IMT, tetapi memberikan pengaruh negative yang signifikan pada kadar $\mathrm{Hb}$ anak.

Tulisan ini mencoba mengungkap hubungan antara rumah tangga migran dengan status kesehatan anak dengan menggunakan data IFLS. Akan tetapi, dalam hal ini masih ada beberapa keterbatasan berkaitan dengan ketersediaan data yang dapat mengungkap tentang jumlah remitan yang diterima, alokasi remitan, dan frekuensi remitan di terima oleh rumah tangga. Informasi tentang remitan sangat penting karena berhubungan dengan pendapatan rumah tangga dan alokasi pemanfaatan remitan oleh rumah tangga. 


\section{DAFTAR PUSTAKA}

Alatas, S, 1993, “Beberapa Aspek Ekonomi dari Migrasi Penduduk", Lembaga Demografi FEUI, Paper Series, No,12, September.

Astuti, T.M.P., 2009, Sosialisasi Anak dan Melemahnya Tradisi dalam Migrasi Internasional (Kasus TKW dari Gondongan Grobogan Jawa Tengah), Jurnal Humaniora,Vol.21, No.2 Juni 2009, 125-137.

Bhandari, R, 2000, Education and Food Consumption Patterns in China: Household Analysis and Policy Implications,Journal of Nutrition Education, Volume 32, Issue 4, Pages 214-224, July 2000. http:// www.journals.elsevierhealth.com/ periodicals/jned/article/S00223182\% 2800\%2970559-0/abstract.

Child Health and Migration Parents in Southeast Asia (CHAMPSEA)Thailand Report / Aree Jampaklay ... [et. al.]. -- 1st ed. -- Nakhon Pathom : Institute for Population and Social Research, Mahidol University, 2012. (Publication / Institute for Population and Social Research, Mahidol University ; no. 399). http://www.google. co.id / \#output=search\&sclient=psyab\&q $=$ Child + Health + and + Migr ation+Parents+in+Southeast + Asi a+\% 28CHAMPSEA \% 29-+Thaila $\mathrm{nd}+$ Report $\% 2 \mathrm{~F}+$ Aree + Jampakl ay\&oq $=$ Child + Health + and + Migr ation+Parents+in+Southeast + Asi a+\% 28CHAMPSEA \% 29-+Thailan $\mathrm{d}+$ Report $+\% 2 \mathrm{~F}+$ Aree+Jampaklay \&gs_1=hp.3...5392.5392.0.6699.1.1. 0.0.0.0.441.441.4-1.1.0...0.0...1c.1.12. psy-ab.1DIw MpPubqI\&pbx= $1 \& b$ a $v=o n \cdot 2, o r \cdot r$ qf.\&bvm $=$ bv. $45960087, \mathrm{~d}$. bmk\&fp=ad 595f020d47a3b9\&biw =1280\&bih=624

Definition of the Children, in CRC : section II, artikel 1. (http:/ / wcd.nic.in/crcpdf/ CRC-2.PDF)-12-10-2011
Escalante, N.G., et al, 2008, Effect of Labor Migration on The Health of Children Left Behind, Capitol University Research and Extension Office, Institute of Development Studies, Cagayan de Oro City, Philippines, in Governance in a Tryptych : Environment, Migration, Peace and Order, 23-25 October 2008, Manila, Philippines.

Feinstein, L, et.al, 2006, What are the Effect Education on Health. In Measuring The Effect of Education on Health and Civic Management : Proceeding of the Copenhagen Symposiun, OECD. http://www.google. co.id/ \#sclient $=$ psy-ab\&q $=$ What + are + the + Effect + Education + on $+\mathrm{H}$ ealth.+In+Measuring+The+Effec $\mathrm{t}+\mathrm{of}+$ Education $+\mathrm{on}+$ Health + and + Civic+Management+:+Proceedi ng+of +the+Copenhagen + Sympos iun $\% 2 C+O E C D \& o q=W h a t+$ are $+t$ he+Effect+Education+on+Health. + In+Measuring + The + Effect + of $+E$ ducation + on + Health+and + Civic + Management+:+Proceeding $+\mathrm{of}+\mathrm{t}$ he+Copenhagen + Symposiun $\% 2 \mathrm{C}$ +OECD\&gs_l=hp.3...215645.21687 1.1.217960.1.1.0.0.0.0.0.0..0.0...0.1.. .1c.1.12.psy-ab.sDpAlVDc1g4\&pbx= $1 \& \mathrm{~b}$ a v $=\mathrm{o} \mathrm{n} \cdot 2, \mathrm{or} \cdot \mathrm{r}$ qf. \&bvm $=$ bv .45960087, d.bmk\&fp= a d 595 f 020 d 47 a 3 b $9 \&$ bi w $=$ $1280 \&$ bih $=624$

Hardiyansyah, 2007, Review on Determinant Factors of Dietary Diversity, Jurnal Gizi dan Pangan, Juli 2007 2(2) : 5574 . http://fema.ipb.ac.id/en/wpcontent/uploads/2010/03/Reviewdeterminan-konsumsi.pdf.

Hugo, G, 1978,Population in West Java, Yogyakarta : Gadjah Mada University Press.

Lee, E.S., 1970, “A Theory of Migration", Population Geography : A Reader. Ed. George J, Demko, Harrold M, Rose and George A Schnell, New York 
: Mc. Graw-Hill Book Company, p 288-298.

Mantra, I.B., 1978, Population Movement in Wet-Rice Communities : A Case Study of Two Dukuh in Yogyakarta Special Region, Honolulu: Department of Geography, University of Hawaii, Ph.D. Thesis, University of Hawaii.

Stillman, S, et al, 2007, The Impact of Immigration on Child Health: Experimental Evidence from a Migration Lottery Program. h t t p : / / w m s-soros.mngt. waikato.ac.nz/NR/rdonlyres/ e mxgj6d hbqubygma $6 \times 6 \mathrm{~m} 7$ uxcjsvhefz 4 xsrsmb7xafqrblp4 pconudp4hzcappcbbauf6ktourosuf/ PIChildHealthdrafttoJHR2.pdf.

Salah, M.A., 2008, The Impact of Migration on Children in Moldova, Policy,
Advocacy and Knowledge Management (PAKM), Division of Policy an Practice, UNICEF. New York. http://www.unicef. org/The_Impacts_of_Migration_ on_Children_in_Moldova $\% 281 \% 29$. pdf

Todaro, M.P., 1996, “Economics of Internal Migration in Developing Countries : A Review of Models", Michael P, Todaro Ed,Migration in Developing Countries, Geneva : ILO, pp. 21-46.

United Nations, 1970, Manuals on Methods of Estimating Population, Manual VI : Methods of Measuring Internal Migration, Manual VI, Departement of Economic and Social Affairs, Population Studies N0.47, New York. 